\begin{tabular}{lc}
\hline CURRENT & ISSN: 0973-4929, Vol. 13, No. (3) 2018, Pg. 307-316 \\
WORLD & Current World Environment
\end{tabular}

ENVIRONMENT Journal Website: www.cwejournal.org

\title{
Forest Fire Risk Assessment using Fuzzy Analytic Hierarchy Process
}

\section{DIVYA MEHTA, PARMINDER KAUR BAWEJA and R K AGGARWAL*}

Department of Environmental Science, College of Forestry, DrY S Parmar

University of Horticulture and Forestry Nauni, Solan, 173 230, India.

\begin{abstract}
The goal of present investigation was to generate forest fire risk zones in Solan district of Himachal Pradesh. The methodology applied was based on Fuzzy Analytic Hierarchy Process (FAHP) technique which involved socio-economic and bio-physical factors for risk assessment. Risk factors were selected on the bases of occurrence of forest fire in the area during past few years. Results revealed highest weight for fuel type (0.3109) followed by aspect (0.2487), agricultural workers $(0.1341)$, nutritional density $(0.1244)$, population density $(0.0622)$, slope $(0.0524)$, elevation $(0.0311)$, literacy rate $(0.0207)$ and distance from road $(0.0155)$, respectively. Out of total geographical area, $4.15 \%$ area was classified under very high risk, while $40.63 \%$ and $54.00 \%$ area was under high and moderate risk, respectively. Area under low risk (0.84\%) and very low risk $(0.37 \%)$ were extremely less. The results were in agreement with actual fire occurrences in the area.
\end{abstract}

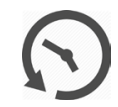

Article History

Received: 17 July 2018

Accepted: 21 November 2018

\section{Keywords}

Cumulative Fire Risk Index;

FAHP;

Forests Fire;

Index modeling;

MCDA;

Risk assessment.

\section{Introduction}

Forest fires are extensive and critical facet of the world. The annual global area burned due to forest fire ranges from 300 and 450 Mha. ${ }^{1}$ Over 80 percent of the global area burned occurs in grasslands and savannahs, primarily in South Asia, Africa, Australia and South America. Globally fires are frequent over most of the earth except in areas of scant vegetation and near the poles. ${ }^{2}$

India witnesses most of severe forest fires during the summer season in the hills of Himachal Pradesh. ${ }^{3}$

CONTACT R K Aggarwal 1 rajeev1792@ rediffmail.com 9 Department of Environmental Science, College of Forestry, Dr Y S Parmar University of Horticulture and Forestry Nauni, Solan, 173 230, India.

\section{(c) (i)}

(c) 2018 The Author(s). Published by Enviro Research Publishers.

This is an Open Access article licensed under a Creative Commons license: Attribution 4.0 International (CC-BY).

Doi: http://dx.doi.org/10.12944/CWE.13.3.05 
Forest fires have caused extensive damage in recent years leading to loss of wildlife habitat and biodiversity, change in micro-climate, adverse effect on livelihood of people, addition of greenhouse gases etc. Average estimated loss due to forest fire in Himachal Pradesh is INR 113 million per annum. ${ }^{4}$ The forests of Himachal Pradesh are mainly comprised of Chir, Oak, Deodara, Khair, Saal, Bamboo and other broad-leaved tree species. Out of above species area occupied by Chir is highly prone to forest fires due to shedding of highly inflammable chir needles. ${ }^{5}$ The forests of the Solan district are occupied by pure and mixed stands of chir pine and mostly conform to lower Shiwalik chir pine $\left(9 \mathrm{C}_{1} \mathrm{a}\right)$ forest type and covers 7.68 per cent of total area of district. ${ }^{5-6}$ There was need to generate forest fire risk zone for the study area in order to carry out prevention and management measures.

Common practice of Forest Fire Risk Zones has been delineated by assigning knowledge base weights to the risk factor classes according to their sensitivity to fire. Fuzzy Analytic Hierarchy Process (FAHP) has been used as multi-criteria decision analysis (MCDA) tool for weight estimation. ${ }^{7-9}$

\section{Study Area}

The study was carried out in Solan district of Himachal Pradesh, India. Solan occupied 10 percent area of the state i.e. 1,93,600 hectares. The area was primarily occupied by Pinus roxburghii,
Quercus leucotric hophora, Acacia catechu, bamboos and other broad leaved tree species. Average daily mean temperature, relative humidity and annual rainfall were $18.4^{\circ} \mathrm{C}, 1038.2 \mathrm{~mm}$ and $51.2 \%$, respectively.

\section{Materials and Methods}

In this investigation Saaty's (1998) ${ }^{7}$ Fuzzy Analytic Hierarchy Process (FAHP) was used. FAHP is Multicriteria Decision Making methodology which involves decision-making framework to rank and prioritize the forest fire risk factors. Table 1 summarizes the related work done over the world.

\section{Hierarchical Structure Development of Fire Risk Criteria}

We used population density (PD), agricultural workers (AGRI-W), literacy rate (LR) nutritional density (ND), distance from road (DR), fuel type $(F T)$, aspect $(A)$, slope (S) and elevation (E) for evaluating the fire risk in the study area (Fig. 2).Fuzzy Analytic Hierarchy model was followed in order to construct the hierarchical structure, for reckoning fire risk (Fig. 2).

Relevant socio-economic data for sub-districts of Solan were collected from District Census Handbook. Road maps, Terrain maps and fuel type maps were generated using Shuttle RADAR Topographic Mission (90m), GLOBE COVER (300m) and GLCF, respectively.

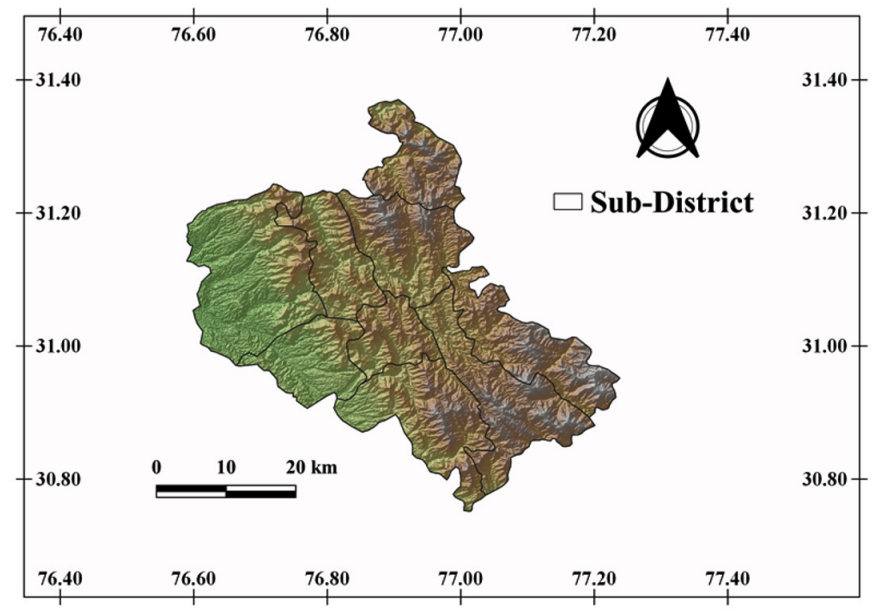

Fig. 1 
Table 1. Summary of Related Works

\begin{tabular}{|c|c|c|c|c|}
\hline First Author & Year & Place of Study & Title of Research Work & $\begin{array}{l}\text { Variable Studied and } \\
\text { Fire Risk Model }\end{array}$ \\
\hline Aumedes ${ }^{10}$ & 2017 & Global & $\begin{array}{l}\text { Human-caused fire occurrence } \\
\text { modelling in perspective: a review }\end{array}$ & $\begin{array}{l}\text { Distance from roads, railways, } \\
\text { urban areas and settlements } \\
\text { Model: HCF model } \\
\text { (Human Caused Fire) }\end{array}$ \\
\hline Ruffault ${ }^{11}$ & 2017 & France & $\begin{array}{l}\text { Contribution of human and } \\
\text { biophysical factors to the spatial } \\
\text { distribution of forest fire ignitions } \\
\text { and large wildfires in a French } \\
\text { Mediterranean region }\end{array}$ & \\
\hline Ajin ${ }^{12}$ & 2016 & $\begin{array}{l}\text { Kerala, } \\
\text { India }\end{array}$ & $\begin{array}{l}\text { Forest Fire Risk Zone Mapping Using } \\
\text { RS and GIS Techniques: A Study in } \\
\text { Achankovil Forest Division, } \\
\text { Kerala, India. }\end{array}$ & $\begin{array}{l}\text { Distance from roads and } \\
\text { distance from settlements } \\
\text { Model: FRI (Fire Risk Index) }\end{array}$ \\
\hline Baweja $^{13}$ & 2014 & $\begin{array}{l}\text { Himachal } \\
\text { Pradesh, } \\
\text { India }\end{array}$ & $\begin{array}{l}\text { Perceptions of communities } \\
\text { exposed to forest fires in western } \\
\text { Himalayan region of India. }\end{array}$ & Family size and literacy rate \\
\hline Vilar $^{14}$ & 2014 & Europe & $\begin{array}{l}\text { Modelling socio-economic drivers } \\
\text { of forest fires in the Mediterranean } \\
\text { Europe. }\end{array}$ & $\begin{array}{l}\text { Population density, road networks, } \\
\text { wildland-urban interface, railway } \\
\text { network, protected area, landscape } \\
\text { fragmentation etc. } \\
\text { Model: Logistic Regression Model }\end{array}$ \\
\hline Spies $^{15}$ & 2014 & Oregon & $\begin{array}{l}\text { Examining fire-prone forest land } \\
\text {-scapes as coupled human and } \\
\text { natural systems }\end{array}$ & Ownership of land \\
\hline Ganteaume ${ }^{16}$ & 2013 & Europe & $\begin{array}{l}\text { A review of the main driving } \\
\text { factors of forest fire ignition over } \\
\text { Europe. }\end{array}$ & $\begin{array}{l}\text { Unemployment rate, transport } \\
\text { networks and distance to urban } \\
\text { areas }\end{array}$ \\
\hline Lafragueta ${ }^{17}$ & 2013 & Spain & $\begin{array}{l}\text { GIS and MCE-based forest fire } \\
\text { assessment and mapping- A case } \\
\text { study in Huesca, Aragon, Spain. }\end{array}$ & $\begin{array}{l}\text { Distance from roads, railway track, } \\
\text { camping and settlements } \\
\text { Model: FRI (Fire Risk Index) }\end{array}$ \\
\hline Sharma $^{18}$ & 2012 & $\begin{array}{l}\text { Himachal } \\
\text { Pradesh, } \\
\text { India }\end{array}$ & $\begin{array}{l}\text { Fuzzy AHP for forest fire risk } \\
\text { modeling }\end{array}$ & $\begin{array}{l}\text { Distance from road and distance } \\
\text { from settlement } \\
\text { Model: CFRISK (Cumulative Fire } \\
\text { Risk Index) }\end{array}$ \\
\hline Gai $^{19}$ & 2011 & China & $\begin{array}{l}\text { GIS-based Forest Fire Risk } \\
\text { Assessment and Mapping }\end{array}$ & $\begin{array}{l}\text { Population density and value } \\
\text { of forest resources } \\
\text { Model: FRI (Fire Risk Index) }\end{array}$ \\
\hline Hoyo $^{20}$ & 2011 & Spain & $\begin{array}{l}\text { Logistic regression models for } \\
\text { human-caused wildfire risk estimation: } \\
\text { analysing the effect of the spatial } \\
\text { accuracy in fire occurrence data }\end{array}$ & $\begin{array}{l}\text { Road infrastructure, recreational } \\
\text { and natural protected areas, } \\
\text { Cattle-grazing pressure, Buffer } \\
\text { of electric lines etc. } \\
\text { Model: Logistic Regression Models }\end{array}$ \\
\hline Archibald $^{21}$ & 2010 & South Africa & $\begin{array}{l}\text { Southern African fire regimes as } \\
\text { revealed by remote sensing }\end{array}$ & $\begin{array}{l}\text { Population density } \\
\text { Model: FRP (Fire Radiative Power } \\
\text { Index) }\end{array}$ \\
\hline
\end{tabular}




\begin{tabular}{|c|c|c|c|c|}
\hline First Author & Year & Place of Study & Title of Research Work & $\begin{array}{l}\text { Variable Studied and } \\
\text { Fire Risk Model }\end{array}$ \\
\hline Calcerrada $^{22}$ & 2010 & Spain & $\begin{array}{l}\text { Spatial modelling of socioeconomic } \\
\text { data to understand patterns of } \\
\text { human-caused wildfire ignition risk } \\
\text { in the SW of Madrid (central Spain) }\end{array}$ & $\begin{array}{l}\text { Population, secondary housing, } \\
\text { cattle, sheep and goats }\end{array}$ \\
\hline Vadrevu ${ }^{23}$ & 2010 & $\begin{array}{l}\text { Andhra } \\
\text { Pradesh, } \\
\text { India }\end{array}$ & $\begin{array}{l}\text { Fire Risk Evaluation using multi- } \\
\text { criteria analysis- A case study }\end{array}$ & $\begin{array}{l}\text { Population density, agri- } \\
\text { cultural workers, nutritional density } \\
\text { and literacy rate } \\
\text { Model: Analytical Hierarchy } \\
\text { Process (AHP) }\end{array}$ \\
\hline Leone $^{24}$ & 2009 & $\begin{array}{l}\text { Mediterranean } \\
\text { region }\end{array}$ & $\begin{array}{l}\text { Human factors of fire occurrence } \\
\text { in the Mediterranean }\end{array}$ & $\begin{array}{l}\text { Agricultural burning, bonfires, } \\
\text { power line, engines, machines etc. }\end{array}$ \\
\hline Martinez $z^{25}$ & 2008 & Spain & $\begin{array}{l}\text { Human-caused wildfire risk rating } \\
\text { for prevention planning in Spain }\end{array}$ & $\begin{array}{l}\text { Rural exodus, forest lands, rural } \\
\text { population aging or declining } \\
\text { fuel accumulation in abandoned } \\
\text { agricultural lands, lack of interest } \\
\text { in conservation etc. } \\
\text { Model: Logistic Regression Model }\end{array}$ \\
\hline Maingi ${ }^{26}$ & 2007 & $\begin{array}{l}\text { United States } \\
\text { of America }\end{array}$ & $\begin{array}{l}\text { Factors influencing wildfire } \\
\text { occurrence and distribution } \\
\text { in eastern Kentucky, USA }\end{array}$ & $\begin{array}{l}\text { Unemployment rates, distance } \\
\text { to roads and distance to populated } \\
\text { places. }\end{array}$ \\
\hline Yang $^{27}$ & 2007 & United States & $\begin{array}{l}\text { Spatial Patterns of Modern Period } \\
\text { Human-Caused Fire Occurrence in } \\
\text { the Missouri Ozark Highlands }\end{array}$ & $\begin{array}{l}\text { Roads, municipalities, ownership, } \\
\text { and population density }\end{array}$ \\
\hline Rawat ${ }^{28}$ & 2003 & $\begin{array}{l}\text { Uttarakhand, } \\
\text { India }\end{array}$ & $\begin{array}{l}\text { Fire Risk Assessment for Forest } \\
\text { Fire Control Management } \\
\text { in Chilla Forest Range of Rajaji } \\
\text { National Park, Uttaranchal, India }\end{array}$ & $\begin{array}{l}\text { Road index and settlement index } \\
\text { Model: CFRISK (Cumulative Fire } \\
\text { Risk Index) }\end{array}$ \\
\hline
\end{tabular}

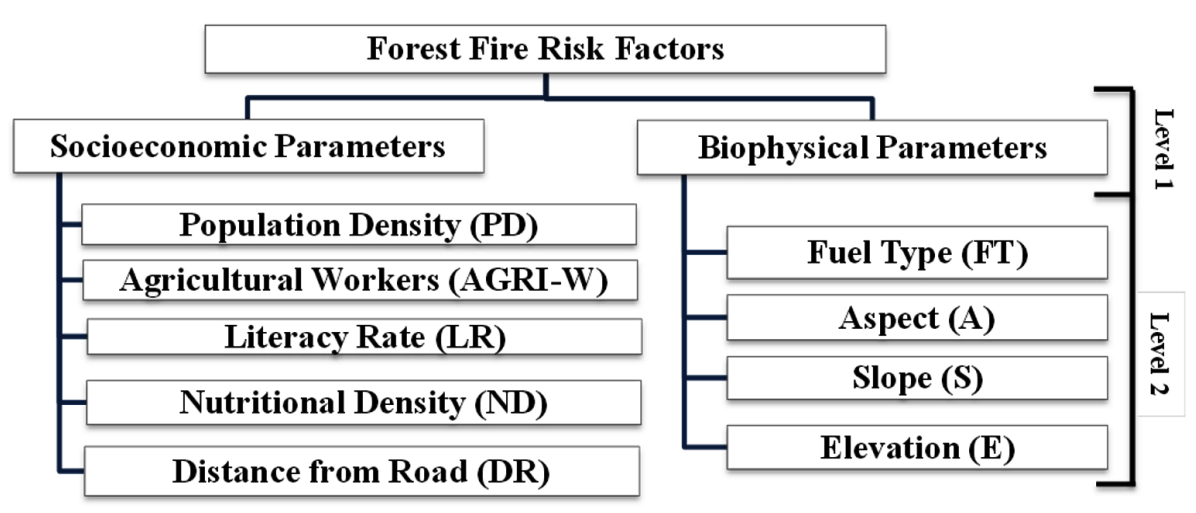

Fig. 2: Hierarchial Data Organization for Quantifying Fire Risk in the Study Area 
Table 2: Index Value and Fire Rating Classes for Forest Fire Risk Parameters

\begin{tabular}{lccl}
\hline Parameter & Class & Index Value & Fire rating class \\
\hline Population Density & & & \\
$\left(\right.$ People $\left.\mathbf{~ k m}^{-2}\right)$ & $0-150$ & 1 & Very low \\
& $150-300$ & 2 & Low \\
& $300-450$ & 3 & Moderate \\
& $450-600$ & 4 & High \\
& $\geq 600$ & 5 & Very high
\end{tabular}

Literacy Rate

(\%)

$\begin{array}{ccl}0-20 & 5 & \text { Very high } \\ 20-40 & 4 & \text { High } \\ 40-60 & 3 & \text { Moderate } \\ 60-80 & 2 & \text { Low } \\ 80-100 & 1 & \text { Very low }\end{array}$

Agricultural Workers (people)

$\begin{array}{ccl}0-5000 & 1 & \text { Very low } \\ 5000-10000 & 2 & \text { Low } \\ 10000-15000 & 3 & \text { Moderate } \\ 15000-20000 & 4 & \text { High } \\ \geq 20000 & 5 & \text { Very high }\end{array}$

Nutritional Density

(People km-2)

$$
\begin{gathered}
0-100 \\
100-200 \\
200-300 \\
300-400 \\
\geq 400
\end{gathered}
$$

Distance from Road Network

(km)

Fuel Type

$0-1.00$
$1.00-2.00$
$2.00-3.00$
$3.00-4.00$
$\geq 4.00$

Conifer Forest
Broad-leaved Forest
Mixed Forest
Scrub Lands
Cultivated Areas
Urban Areas
Bare Areas

\section{5}

4

3

2

1

\section{5}

4

3

2

2

1

1
Very low

Low

Moderate

High

Very high
Very high

High

Moderate

Low

Very low

Very high

High

Moderate

Low

low

Very low

Very low 


\begin{tabular}{lccl}
\hline Parameter & Class & Index Value & Fire rating class \\
\hline Aspect & North & 1 & Very low \\
& Northeast & 1 & Very low \\
& Northwest & 2 & Low \\
& West & 2 & Low \\
& East & 3 & Moderate \\
& Southeast & 4 & High \\
& Southwest & 5 & Very high \\
Elevation & South & 5 & Very high \\
(m) & & & \\
& $\leq 500$ & 5 & Very high \\
& $500-1000$ & 4 & High \\
& $1000-1500$ & 3 & Moderate \\
& $1500-2000$ & 2 & Low \\
Slope & $\geq 2000$ & 1 & Very low \\
(degree) & $0-10$ & 1 & Very low \\
& $10-20$ & 2 & Low \\
& $20-30$ & 3 & Moderate \\
& $30-40$ & 4 & High \\
& $\geq 40$ & 5 & Very high \\
\hline
\end{tabular}

\section{Forest Fire Risk Index}

All factors were classified into five classes, where higher value represented more risk as compared to the lower values (Table 2).

\section{Fuzzy Analytic Hierarchy Process (FAHP)}

FAHP was used for determining weights for the parameters. A judgmental pair wise comparison matrix ' $A$ ', was formed using the comparison scales (Table 3). Each entry $a_{i j}$ of the matrix 'A' was formed comparing the row element $a_{i}$ with the column element $a_{j^{*}}{ }^{29}$

$A=\left(a_{i j}\right)(i, j \ldots n=1,2 \ldots n ; n=$ number of criteria $)$

The entries $a_{i j}$ in matrix ' $A$ ' were done following rules given below:

$$
a_{i j}>0 ; a_{i j}=\frac{1}{a_{j i}} ; a_{i i}=1 \text { for all } \mathrm{i}
$$

$$
\mathbf{A}=\left[\begin{array}{ccc}
a_{11} \cdots & a_{1 j} \cdots & a_{1 n} \\
\vdots & \vdots & \vdots \\
1 / a_{1 j} \cdots & a_{j j} \cdots & a_{j n} \\
& \vdots & \vdots \\
\vdots & & \\
1 / a_{1 n} \cdots & 1 / a_{j n} \cdots & a_{n n}
\end{array}\right]
$$

Standardized matrix 'W' was formed by using following equation:

$$
W=\left(w_{i j}\right)=\frac{a_{i j}}{\sum_{j=1}^{n} a_{i j}}
$$

Final weights were derived by taking row average of matrix 'W'.

Table 3: Scale used in Fuzzy Analytical Hierarchy Process ${ }^{30}$

\begin{tabular}{ll}
\hline $\begin{array}{l}\text { Intensity } \\
\text { of scale }\end{array}$ & Linguistic Variable \\
\hline 1 & Equally important \\
3 & Weakly important \\
5 & Essentially important \\
7 & Very strongly important \\
9 & Absolutely important \\
$2,4,6,8$ & intermediate values between \\
& two adjacent judgments \\
\hline
\end{tabular}



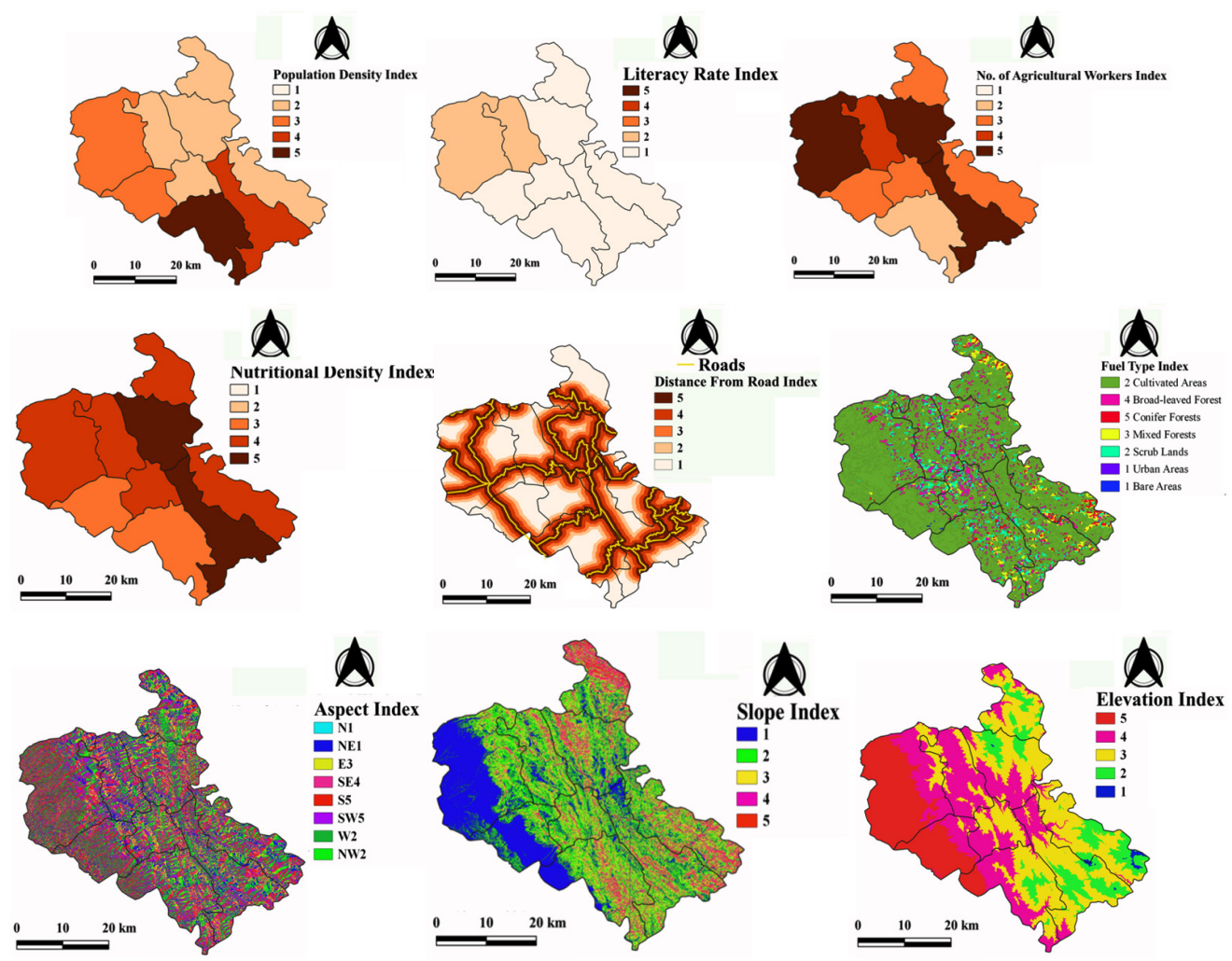

Fig. 3: Index Map for Socio-Economic and Bio-Physical Factors

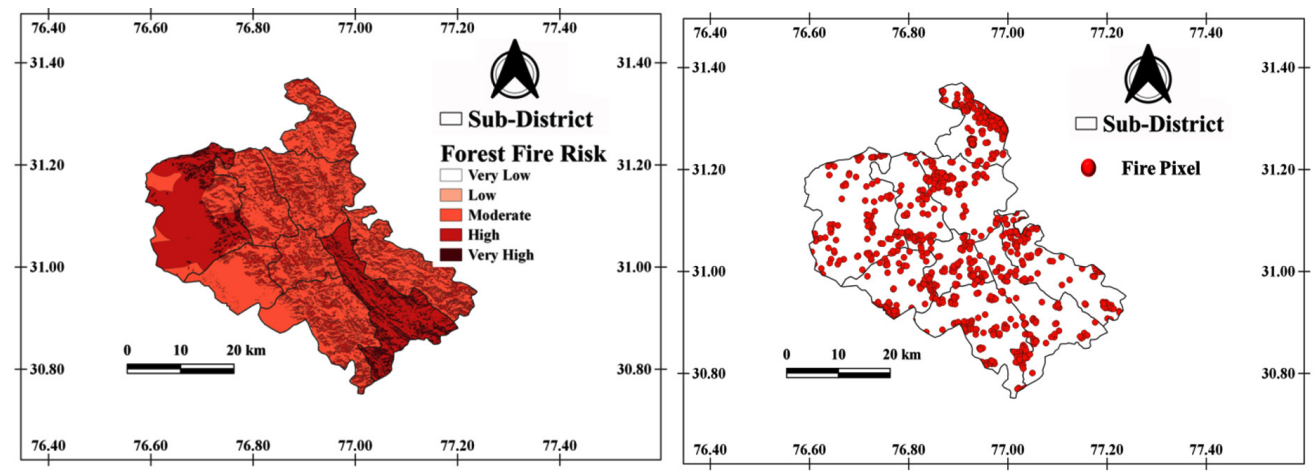

Fig. 4: (a) Forest Fire Risk Map for Solan district and

(b) Forest Fire hot spot derived from NASA FIRMS datasets for the year 2018 
Table 4: Estimated Weights of Forest Fire Risk Parameters

\begin{tabular}{llll}
\hline Socio-economic Parameter & Weight & Bio-physical Parameter & Weight \\
\hline Population density (person km-2) & 0.0622 & Fuel type & 0.3109 \\
Literacy rate (\%) & 0.0207 & Aspect & 0.2487 \\
Agricultural workers (person) & 0.1341 & Slope (degree) & 0.0524 \\
Nutritional density (person km ${ }^{-2}$ ) & 0.1244 & Elevation (m) & 0.0311 \\
Distance from road (m) & 0.0155 & & \\
\hline
\end{tabular}

\section{Consistency of comparisons}

The value of $K_{\max }$ was required to calculate the consistency ratio $(\mathrm{CR}){ }^{24}$

Consistency index $(\mathrm{Cl})=\left(K_{\max }-\mathrm{n}\right) /(\mathrm{n}-1)$

Where,

$\Lambda_{\max }=$ largest eigen value and $\mathrm{n}=$ number of criteria

The final consistency ratio was calculated by dividing the consistency index with the random index

$$
\mathrm{CR}=\mathrm{Cl} / \mathrm{RI}
$$

Where,

$\mathrm{RI}=$ Random index and $\mathrm{Cl}=$ Consistency index

Consistency ratio was designed such a way that shows a reasonable level of consistency in the pair wise comparisons if $\mathrm{CR}<0.10$ and $\mathrm{CR} \geq 0.10$ indicated inconsistent.

\section{Results and Discussion}

Results pertaining to estimated weights of selected fire risk factors revealed highest weight for fuel type (0.3109) followed by aspect (0.2487), agricultural workers (0.1341), nutritional density (0.1244), population density (0.0622), slope (0.0524), elevation (0.0311), literacy rate $(0.0207)$ and distance from road $(0.0155)$, respectively (Table 4$)$.

The resulting weights from Fuzzy Analytic Hierarchy Process were applied in the Cumulative Forest Fire Risk Index model. Table 5 demonstrated the fire risk for five classes of CFRISK index value. CFRISK model had been shown in the following equation:-

CFRISK $=0.0622^{*} \mathrm{PDI}+0.0207^{*} \mathrm{LRI}+0.1341^{*} \mathrm{AWI}+$ $0.1244^{\star} \mathrm{NDI}+0.0155^{\star} \mathrm{DRI}+0.3109^{\star} \mathrm{FTI}+0.0524^{\star} \mathrm{SI}+$

\section{$0.2487^{\star} \mathrm{Al}+0.0311^{\star} \mathrm{El}$}

Where;

CFRISK $=\quad$ Cumulative Fire Risk Index

$\mathrm{PDI}=\quad$ Population density index

$\mathrm{LRI}=\quad$ Literacy rate index

$\mathrm{AWI}=\quad$ Agricultural worker index

$\mathrm{NDI}=\quad$ Nutritional density index

$\mathrm{DRI}=\quad$ Distance from road index

$\mathrm{FTI}=\quad$ Fuel type index

$\mathrm{SI}=\quad$ Slope index

$\mathrm{Al}=\quad$ Aspect index

$\mathrm{EI}=\quad$ Elevation Index

Out of total geographical area of Solan district, $4.15 \%$ area was classified under very high risk, $40.63 \%$ area under high risk, $54.00 \%$ area under moderate risk, $0.84 \%$ area under low risk and $0.37 \%$ under very low risk (Fig. 4a).Accuracy of the Forest Fire Risk map was tested using NASA FIRMS forest fire dataset for the year 2018 (Fig. 4b). The Forest Fire Risk map for the three classes alone viz. moderate, high and very high predicted $99.4 \%$ of the total fire pixels (1012). The moderate class predictive capability was highest $(60.77 \%)$, followed by high (33.99\%) and very high (4.64\%) fire risk class.

Table 5: Cumulative Forest Fire Risk (CFRISK) Index potential scale ${ }^{24}$

\begin{tabular}{ll}
\hline Index & Forest Fire Risk \\
\hline $0-1$ & Very low \\
$1-2$ & Low \\
$2-3$ & Moderate \\
$3-4$ & High \\
$4-5$ & Very high \\
\hline
\end{tabular}




\section{Acknowledgements}

The assistance provided by Dr SK Bhardwaj Prof. \&Head, Department of Environmental Science, and Dr IK Thakur, Principal Scientist, Department of Tree
Improvement and Genetic Resources, DrYS Parmar University of Horticulture and Forestry, Nauni, HPIndia in the present study is highly acknowledged.

\section{References}

1. Van der Werf, G.R., Randerson, J.T., Giglio, L., Collatz, G.J., Kasibhatla, P.S., and Arellano, Jr. A.F., Interannual variability in global biomass burning emissions from 1997 to 2004. Atmosphere Chemistry Physics, 6(11):3423-3441 (2006).

2. Mouillot, F., and Field, C.B., Fire history and the global carbon budget: A fire history reconstruction for the 20th century. Global Change Biology, 11(3):398-420 (2005).

3. Forest Survey of India. State forest report, Dehradun, Uttarakhand; (2003).

4. Anonymous. Forest fires and its effect on environment, forests, bio-diversity and remedial/preventive measures. Directory of Forest Fire Control and Management, Himachal Pradesh ;(2016).

5. Shah, S., and Sharma, D.P., Land use change detection in Solan Forest Division, Himachal Pradesh, India. Forest Ecosystems, 2:26-38 (2015).

6. Champion, H.G., and Seth, S.K., A Revised Survey of Forest Types of India. Management of Publications, Govt. of India, Delhi. 34p, (1968).

7. Saaty, L.T., Multicriteria Decision Making: The Analytic Hierarchy Process, RWS Publications, Pittsburgh, PA, (1988).

8. Vaidya, O.S., and Kumar, S., Analytic hierarchy process: An overview of applications. European Journal of Operational Research, 169(1):1-29 (2006).

9. Vahidniaa, M.H., Alesheikhb, A., Alimohammadic, A., and Bassirid, A., Fuzzy Analytical Hierarchy Process in GIS application. The International Archives of the Photogrammetry, Remote Sensing and Spatial Information Sciences,37:593-596 (2008).

10. Aumedes, S.C., Comas, C., and Garcia, V.C., Human-caused fire occurrence modelling in perspective: a review. International Journal of
Wildland Fire, 26(12): 983-998 (2018).

11. Ruffault, J., and Mouillot, F., Contribution of human and biophysical factors to the spatial distribution of forest fire ignitions and large wildfires in a French Mediterranean region. International Journal of Wildland Fire, 26(6):498-508 (2017).

12. Ajin, R.S., Loghin, A.M., Vinod, P.G., and Jacob, M.K., Forest Fire Risk Zone Mapping Using RS and GIS Techniques: A Study in Achankovil Forest Division, Kerala, India. Journal of Earth, Environment and Health Sciences,2(3):109 (2016).

13. Baweja, P.K., and Kundu, S., Perceptions of communities exposed to forest fires in western Himalayan region of India. Online International Journal of Biosolution,2(4): 9499 (2014).

14. Vilar, L., Camia, A., and Ayanz, J.S.M., Modelling socio-economic drivers of forest fires in the Mediterranean Europe. In: Social and Economic issues, Coimbra University Press, Spain, 1874-1882 (2014).

15. Spies, T.A., White, E.M., Kline, J.D., Fischer, A.P., Ager, A., Bailey, J., Bolte, J., Koch, J., Platt, E., Olsen, C.S., Jacobs, D., Examining fire-prone forest landscapes as coupled human and natural systems. Ecology and Society, 19(3):9 (2014).

16. Ganteaume, A., Camia, A., Jappiot, M., San-Miguel-Ayanz J., Long-Fournel M., and Lampin C., A review of the main driving factors of forest fire ignition over Europe. Environmental management,51(3): 651-662 (2013).

17. Lafragueta, J.F., GIS and MCE-based forest fire risk assessment and Mapping: A case study in Huesca, Aragon, Spain. M Sc Thesis. School of Engineering and the Built Environment, Spain; (2013).

18. Sharma, L.K., Kanga, S., Singh, M.N., Sinha, S., and Chandra, P.P., Fuzzy AHP for forest 
fire risk modeling. Disaster Prevention and Management: An International Journal, 21(2):160-171 (2012).

19. Gai, C., Weng, W., and Yuan, H., GIS-based forest fire risk assessment and mapping. Paper presented at: Computational Sciences and Optimization (CSO), 2011 Fourth International Joint Conference, 1240-1244 (2011).

20. Hoyo, L.V., Isabel, M.P.M., and Vega, F.J.M., Logistic regression models for human-caused wildfire risk estimation: analyzing the effect of the spatial accuracy in fire occurrence data. European Journal of Forest Research, 130: 983-996 (2011).

21. Archibald, S., Scholes, R.J., Roy, D.P., Roberts, G., and Boschetti, L., Southern African fire regimes as revealed by remote sensing. International Journal of Wildland Fire, 19(7):861-878 (2010).

22. Calcerrada, R., Barrio-Parra, F., Millington, J.D.A., and Novillo, C.J., Spatial modelling of socioeconomic data to understand patterns of human-caused wildfire ignition risk in the SW of Madrid (central Spain). Ecological Modelling, 221(1): 34-45 (2010).

23. Vadrevu, K.P., Eaturu, A., and Badrinath, K.V.S., Fire Risk Evaluation using multicritiria analysis- A case study. Environmental monitoring and assessment, 166:223-239
(2010).

24. Leone, V., Lovreglio, R., Martín, M.P., Martínez, J.,and Vilar, L., Human factors of fire occurrence in the Mediterranean. In: Earth observation of wildland fires in Mediterranean ecosystems; 149-170 (2009).

25. Martinez, J., Garcia, C.V., and Chuvieco, E., Human-caused wildfire risk rating for prevention planning in Spain. Journal of environmental management, 90(2):12411252 (2009).

26. Maingi, J.K., and Henry, M.C., Factors influencing wildfire occurrence and distribution in eastern Kentucky, USA. International Journal of Wildland Fire, 16(1):23-33 (2007).

27. Yang, J., He, H.S., Shifley, S.R., and Gustafson, E.J., Spatial patterns of modern period human-caused fire occurrence in the Missouri Ozark Highlands. Forest science, 53(1):1-15 (2007).

28. Rawat, G.S., Fire Risk Assessment for Forest Fire Control Management in Chilla Forest Range of Rajaji National Park, Uttaranchal, India. M Sc Thesis. International Institute for Geo-information Science and Earth Observation Enscheda, (2003).

29. Ramanathan, A., A note on the use of the analytic hierarchy process for environmental impact assessment. Journal of Environmental Management, 63(1):27-35 (2001). 